\title{
Assessment of microbiological quality of municipal supplied water within Dhaka Metropolis
}

\author{
Rabeya Islam, Ahmad Kamruzzaman Majumder ${ }^{\ddagger}$ and Md. Monzer Hossain Sarker \\ Department of Environmental Science, Stamford University Bangladesh, 744, Satmasjid Road \\ Dhanmondi, Dhaka-1209, Bangladesh
}

Received 14 September 2014/Accepted 15 October 2014

\begin{abstract}
Microbiological health risks related to water quality are persisting issues especially in the developing countries. Present study was conducted to evaluate the microbiological quality of municipal supply water of a defined region within Dhaka metropolis, Bangladesh. A total of 20 water samples were collected from 10 selected pump stations and 10 different consuming points to examine the burden of Salmonella spp., Shigella spp., Citrobactor spp., Escherichia coli, Klebsiella spp., Aeromonas spp. and Vibrio spp. The study also included the evaluation of impacts due to the consumption of municipal water. The results revealed that the quality of municipal supplied water was not microbiologically safe for the consumers and also demonstrated the possible commencement of various diseases including diarrhoea, typhoid, dysentery and others.
\end{abstract}

Key words: Water quality; Public health; Microorganisms

Ease of access to safe water supply is one of the most important determinants of public health status $(1,2)$. Stipulation of the safe state of drinking water underlies the condition when it is free from pathogenic microorganisms and detrimental chemicals with a pleasant taste and clear appearance (3). Microbiologically contaminated water is widely known to be responsible for the transmission of infectious diseases resulting in severe fatality (4). It has been estimated that $80 \%$ of all diseases with approximately one third of deaths within the developing countries are caused by the consumption of microbiologically contaminated waters (5). Poor water quality, lack of sanitation and malpractice of hygiene accounts for around 1.7 million deaths a year round the globe (6). Deterioration of water treatment facilities and the municipal water distribution systems can throw up significant public health threats (7).

Over half of the people living in the large cities of developing countries as in Bangladesh live in informal settlements lacking the facility of potable water supply (8). Dhaka, one of the most densely populated cities of the world, is sectored by several municipal zones with separate establishments of water supply for the inhabitants (9). Dhaka Water Supply and Sewerage Authority (WASA) is the responsible body to supply

†Corresponding Author. Mailing address: Dr. Ahmad Kamruzzaman Majumder, Department of Environmental Science, Stamford University Bangladesh, 744, Satmasjid Road, Dhanmondi, Dhaka-1209; Email: kamrul_sub@hotmail.com. the water needs of the Dhaka metropolis; however, the water supplied by WASA is indeed insufficient to meet the demand, and microbiological quality of the supplied water is often questionable. Instigation of enteric diseases like cholera, diarrhea, dysentery, etc. are often associated with the omnipresent tradition of microbiologically contaminated waters together with insanitary life style.

People within Dhaka city are continuously facing problem to hold the limit of their expenses for having safe drinking water as well as for the purpose of water borne disease mitigation. Based on the above rationales, current study endeavored to assess the microbiological status of the supplied water by WASA in a defined zone of the city along with a possible forecast on the water borne disease commencement.

\section{MATERIALS AND METHODS}

Study Area and collection of Sample. The study area chosen for the current investigation was in the north-western part of Dhaka city with an area of $20 \mathrm{sq} \mathrm{km}$, consisting of approximately 80 water pump stations. Ten (10) samples from pump i.e. supply points, 8 samples from households, 1 sample from hotel and 1 sample from an office (total 20 samples) were collected aseptically in pre-sterilized screw caped bottles. Bottles were marked properly and transported to the laboratory as early as possible for microbiological analysis.

Isolation and identification of water borne microorganisms. Conventional microbiological methods were employed. All the reagents and media were of analytical grade. Samples were serially diluted as and when necessary, and then differential and selective cultural media were used for microbial isolation and enumeration (by the spread plate method) followed by biochemical confirmation of the isolates (10). For the estimation of total viable bacteria (TVB), $100 \mu \mathrm{l}$ of each sample was introduced onto the nutrient agar (NA) followed by incubation at $37^{\circ} \mathrm{C}$ for 24 hours for the observation of total viable bacterial load (10).

An aliquot of $100 \mu \mathrm{l}$ of each sample was spread onto the membrane fecal coliform (MFC) agar and MacConkey agar for the quantification of total fecal 
TABLE 1. Presence of heterotrophic bacteria, E. coli, Klebsiella spp. and faecal coliforms (cfu/ml) in water samples

\begin{tabular}{ccccc}
\hline $\begin{array}{c}\text { Sample } \\
\text { No. }\end{array}$ & $\begin{array}{c}\text { Heterotrophic plate } \\
\text { count }(\mathrm{cfu} / \mathrm{ml})\end{array}$ & $\begin{array}{c}\text { Faecal coliform } \\
\text { count }(\mathrm{cfu} / \mathrm{ml})\end{array}$ & $\begin{array}{c}\text { E. coli } \\
(\mathrm{cfu} / \mathrm{ml})\end{array}$ & $\begin{array}{c}\text { Klebsiella spp. } \\
(\mathrm{cfu} / \mathrm{ml})\end{array}$ \\
\hline 01 & $2.1 \times 10^{8}$ & $1.4 \times 10^{5}$ & 0 & $2 \times 10^{6}$ \\
02 & $\mathrm{TNTC}$ & $3.2 \times 10^{3}$ & 0 & $1.3 \times 10^{3}$ \\
03 & $1.6 \times 10^{4}$ & 0 & 0 & 0 \\
04 & $1.9 \times 10^{5}$ & 0 & 0 & 0 \\
05 & $1.9 \times 10^{5}$ & $4.2 \times 10^{4}$ & 0 & 0 \\
06 & $1.4 \times 10^{5}$ & $4 \times 10^{2}$ & 0 & $1.4 \times 10^{4}$ \\
07 & $5.6 \times 10^{8}$ & $1.8 \times 10^{4}$ & $2.9 \times 10^{5}$ & $4.8 \times 10^{4}$ \\
08 & $4.2 \times 10^{9}$ & $1.4 \times 10^{4}$ & 0 & $\mathrm{TNTC}$ \\
09 & $8 \times 10^{8}$ & 0 & $3.2 \times 10^{4}$ & $4.5 \times 10^{5}$ \\
10 & $3.0 \times 10^{9}$ & $1.8 \times 10^{4}$ & $\mathrm{TNTC}$ & $1.1 \times 10^{6}$ \\
11 & $3.8 \times 10^{9}$ & $1.2 \times 10^{4}$ & $6.6 \times 10^{5}$ & $7.5 \times 10^{4}$ \\
12 & $1.2 \times 10^{9}$ & 0 & 0 & $5.4 \times 10^{4}$ \\
13 & $8.2 \times 10^{9}$ & 0 & 0 & $4.0 \times 10^{5}$ \\
14 & $5.2 \times 10^{9}$ & 0 & 0 & $8 \times 10^{3}$ \\
15 & $4.8 \times 10^{9}$ & 0 & 0 & $2 \times 10^{3}$ \\
16 & $1.6 \times 10^{7}$ & $4 \times 10^{3}$ & 0 & 0 \\
17 & $2.8 \times 10^{8}$ & 0 & 0 & $9 \times 10^{3}$ \\
18 & $8.8 \times 10^{6}$ & $3 \times 10^{3}$ & 0 & $2.6 \times 10^{6}$ \\
19 & $2.9 \times 10^{8}$ & $1.5 \times 10^{4}$ & 0 & $3 \times 10^{3}$ \\
20 & $2.3 \times 10^{7}$ & $2.5 \times 10^{4}$ & 0 & 0 \\
\hline
\end{tabular}

TNTC $=$ Too numerous to count

The odd numbered samples were from supply points and the even numbered samples were from consumer points.

coliforms (TFC), and coliforms (Escherichia coli and Klebsiella spp.), respectively. Plates were incubated for 24 hours at $44.5^{\circ} \mathrm{C}$ and $37{ }^{\circ} \mathrm{C}$ for fecal coliform and coliforms, correspondingly. Ten (10) $\mathrm{ml}$ of sample was transferred into $90 \mathrm{ml}$ of selenite cysteine broth (SCB) and alkaline peptone water (APW) for the enrichment of Salmonella spp., Shigella spp., and vibrio-Aeromonas spp., respectively and incubated at $37^{\circ} \mathrm{C}$ for 4-6 hours. After incubation, samples were spread onto Salmonella-Shigella (SS) agar and thiosulfate citrate bile salt sucrose (TCBS) agar for the isolation of Salmonella spp. and Shigella spp., and Vibrio spp., consecutively, followed by incubation at $37{ }^{\circ} \mathrm{C}$ for $24-48$ hours. Finally, all the isolates were confirmed by the prescribed biochemical tests (10).

\section{RESULTS AND DISCUSSION}

In the present investigation, a significant objective based on the detection of the presence of water pollution indicator microorganisms including $E$. coli, Salmonella spp., Shigella spp., Klebsiella spp., Vibrio spp. and Aeromonas spp. All the 20 samples were found to have a huge load of pathogenic bacteria which were further biochemically identified (Tables 1, 2 \& 3). The samples contained heterotrophic bacteria within a range of $1.6 \times 10^{4}$ to $8.2 \times 10^{9} \mathrm{cfu} / \mathrm{ml}$ (Table 1 ). Among 20 water samples, samples 8, 10, 12 and 14 from consumer points, and samples 11 and 13 from supply points harbored the highest load of heterotrophic bacteria $\left(\sim 10^{9} \mathrm{cfu} / \mathrm{ml}\right)$. Samples 10 and 11 exhibited the presence of all the tested pathogenic bacteria as well except $V$. cholerae. Faecal coliforms were encountered in 13 samples ( 5 from supply points and 8 from consumer points) in a range of $4 \times 10^{2}$ to $2.1 \times 10^{5} \mathrm{cfu} / \mathrm{ml}$. Samples 7 , 9, 10 and 11 were noticed to be contaminated with $E$. coli in an average of $10^{5} \mathrm{cfu} / \mathrm{ml}$. Whereas, Klebsiella spp. were found to be present in 15 samples ( 8 from supply points and 7 from consumer points) ranged from $1.3 \times 10^{3}$ to $2.6 \times 10^{6} \mathrm{cfu} / \mathrm{ml}$ (Table 1$)$.

After enrichment of the samples, no growth of $V$. Cholerae was observed. While, 16 samples (8 samples each from supply and consumer points) were found to be contaminated with Aeromonas spp. up to $10^{5} \mathrm{cfu} / \mathrm{ml}$ (Table 2). The presence of Salmonella spp. was detected in samples $3,7,9,11$ from supply points and sample 10 from consumer point. Unlikely, Shigella spp. were encountered in almost all samples except samples 5 and 6 up to $10^{6} \mathrm{cfu} / \mathrm{ml}$ (Table 2 ).

People use the municipal supplied this water source (WASA in case of Dhaka city) not only for drinking but also for other domestic usages. Unfortunately, often this water supply system gets vigorously contaminated with pathogenic microorganisms resulting in water borne disease complications $(1,4)$. An important aspect must be considered in this aspect that a major fraction of the city's sewage systems remains untreated which in turn crosscontaminate the ground waters and the surface waters. Thus the water supply lines and the content waters may be 
TABLE 2. Presence of Vibrio cholerae, Aeromonas spp., Salmonella spp. and Shigella spp. after enrichment of water samples (cfu/ml)

\begin{tabular}{|c|c|c|c|}
\hline $\begin{array}{l}\text { Sample } \\
\text { No. }\end{array}$ & $\begin{array}{l}\text { Salmonella spp. } \\
(\mathrm{cfu} / \mathrm{ml})\end{array}$ & $\begin{array}{l}\text { Shigella spp. } \\
(\mathrm{cfu} / \mathrm{ml})\end{array}$ & $\begin{array}{l}\text { Aeromonas spp. } \\
(\mathrm{cfu} / \mathrm{ml})\end{array}$ \\
\hline 01 & 0 & $1.1 \times 10^{4}$ & $1.6 \times 10^{5}$ \\
\hline 02 & 0 & $3 \times 10^{3}$ & $2 \times 10^{3}$ \\
\hline 03 & $1.9 \times 10^{4}$ & $1.1 \times 10^{6}$ & $6 \times 10^{2}$ \\
\hline 04 & 0 & $1 \times 10^{5}$ & $7.5 \times 10^{5}$ \\
\hline 05 & 0 & 0 & $1.8 \times 10^{5}$ \\
\hline 06 & 0 & 0 & $9.5 \times 10^{4}$ \\
\hline 07 & TNTC & TNTC & 0 \\
\hline 08 & 0 & TNTC & $2.1 \times 10^{5}$ \\
\hline 09 & $1.4 \times 10^{6}$ & $1.3 \times 10^{5}$ & TNTC \\
\hline 10 & TNTC & TNTC & $3.8 \times 10^{5}$ \\
\hline 11 & $1.5 \times 10^{6}$ & $1.4 \times 10^{5}$ & $1.8 \times 10^{5}$ \\
\hline 12 & 0 & $1.1 \times 10^{5}$ & $1.3 \times 10^{5}$ \\
\hline 13 & 0 & $1.3 \times 10^{5}$ & $2.1 \times 10^{5}$ \\
\hline 14 & 0 & $1.5 \times 10^{5}$ & $2 \times 10^{5}$ \\
\hline 15 & 0 & $1.2 \times 10^{5}$ & $1.9 \times 10^{6}$ \\
\hline 16 & 0 & $6.7 \times 10^{4}$ & $5 \times 10^{4}$ \\
\hline 17 & 0 & $1.9 \times 10^{5}$ & $1.3 \times 10^{5}$ \\
\hline 18 & 0 & $2.5 \times 10^{6}$ & 0 \\
\hline 19 & 0 & $2.9 \times 10^{6}$ & 0 \\
\hline 20 & 0 & $1.4 \times 10^{6}$ & 0 \\
\hline
\end{tabular}

TNTC $=$ Too numerous to count

The odd numbered samples were from supply points and the even numbered samples were from consumer points.

Vibrio cholerae was absent in all the samples.

propagated especially by the fecal coliforms. Moreover, as revealed from the presented data, existence of pathogens in the supply points is indicative of poor treatment strategies of the supplied waters. Substantial consideration should be thus given into the microbial reduction within water prior to supply across the pipelines within the distribution system.

\section{CONCLUSIONS}

The presented data referred that the quality of municipal supplied water were not safe for the consumers and was also indicative of the possibilities to impart various enteric diseases. The situation may aggravate in near future if the authority does not pay attention and take immediate actions to restore water quality in the distribution system. Thus routine microbiological assessment of the municipal supplied water is necessary for the sake of public health management.
TABLE 3. Summary of confirmative biochemical identification of the isolates

\begin{tabular}{|c|c|c|c|c|c|c|c|c|c|c|}
\hline \multirow[b]{2}{*}{$\begin{array}{l}\text { Assumed } \\
\text { organism }\end{array}$} & \multicolumn{3}{|c|}{ TSI } & \multirow{2}{*}{ 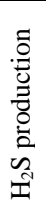 } & \multirow[b]{2}{*}{$\begin{array}{l}\overrightarrow{0} \\
\stackrel{0}{0} \\
\frac{0}{0} \\
\stackrel{\Xi}{\Xi}\end{array}$} & \multirow[b]{2}{*}{$\frac{\tilde{N}}{\stackrel{\Delta}{\Sigma}}$} & \multirow[b]{2}{*}{ 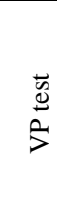 } & \multirow[b]{2}{*}{ 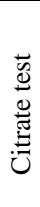 } & \multirow[b]{2}{*}{ 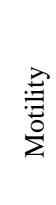 } & \multirow[b]{2}{*}{$\begin{array}{l}\bar{d} \\
0 \\
0 \\
0 \\
0 \\
0\end{array}$} \\
\hline & $\frac{\vec{\Xi}}{\tilde{n}}$ & 芦 & שี & & & & & & & \\
\hline E. coli & Y & $\mathrm{Y}$ & + & - & + & + & - & - & + & - \\
\hline $\begin{array}{l}\text { Klebsiella } \\
\text { spp. }\end{array}$ & Y & $\mathrm{Y}$ & + & - & - & - & + & + & - & - \\
\hline $\begin{array}{c}\text { Salmonella } \\
\text { spp. }\end{array}$ & $\mathrm{R}$ & $\mathrm{Y}$ & - & + & - & + & - & - & + & \\
\hline $\begin{array}{l}\text { Shigella } \\
\text { spp. }\end{array}$ & $\mathrm{R}$ & $\mathrm{Y}$ & + & + & $+/-$ & + & - & - & - & \\
\hline $\begin{array}{c}\text { Aeromonas } \\
\text { spp. }\end{array}$ & $\mathrm{R}$ & $\mathrm{Y}$ & - & - & ND & ND & ND & + & ND & - \\
\hline
\end{tabular}

TSI = Triple sugar iron test; $\mathrm{MR}=$ Methyl red; VP= Voges-Proskauer; $\mathrm{Y}$ $=$ Yellow (acid); $\mathrm{R}=$ Red (alkaline); $\mathrm{ND}=$ Not done

\section{ACKNOWLEDGEMENTS}

Authors thank Dr. Rashed Noor, Associate Professor and Chairman, Department of Microbiology, Stamford University Bangladesh for his cooperation in conducting the research and write up of the manuscript. Authors also thank the Microbiology Laboratory of Stamford University Bangladesh for providing facilities to carry out the experiment.

\section{REFERENCES}

Hrudey, S. E., and E. J. Hrudey. 2007. Published case studies of waterborne disease outbreaks evidence of a recurrent threat. Water Environ. Res. 79: 233245.

2. World Health Organization (WHO). 2000. Towards an assessment of the socioeconomic impact of arsenic poisoning in Bangladesh. World Health Organization, Geneva, Switzerland.

3. Park, K. 1997. Text book of preventive and social medicine, $15^{\text {th }}$ ed. Banarsidas Bhanot. Pub., India.

4. Marshall, J. K., et al. 2006. The Walkerton health study investigation: Incidence and epidemiology of irritable bowel syndrome after a large waterborne outbreak of bacterial dysentery. Gastroenterology 131: 445-450.

5. UNCED. 1992. Protection of the quality and supply of freshwater resources: Application of integrated approaches to the development, management and use of water resources. The United Nations Conference on Environment and Development.

6. Reynolds, K. A., K. D. Mena, and C. P. Gerba. 2007. Risk of waterborne illness via drinking water in the United States. Rev. Environ. Contam. Toxicol. 192: 117-158.

7. Semenza, J., et al. 1998. Water distribution system and diarrheal disease transmission: a case study in Uzbekistan. American Journal of Tropical Medicine and Hygiene 59 (6): 941-6.

8. UN-HABITAT. 2003. Guide to monitoring target 11: Improving the lives of 100 million slum dwellers. United Nations Human Settlements Programme, Nairobi.

9. BBS. 2009. Statistical yearbook of Bangladesh 2009. Bangladesh Bureau of Statistics.

10. Cappuccino J. G., and N. Sherman. 1996. Microbiology: A laboratory manual, $4^{\text {th }}$ ed. The Benjamin/Cummings Publishing Co., Inc., Menlo Park, California. 